\title{
Taxonomic Studies on the Genus Cissus L. (Vitaceae) Present in Obio/Akpor Local Government Area of Rivers State, Nigeria
}

\author{
ONYEWEAKU, GC; NYANANYO, BL; *OZIMEDE, CO
}

\author{
Department of Plant Science and Biotechnology, University of Port Harcourt, Choba, Port Harcourt, Rivers State, Nigeria \\ *Corresponding Author Email: ozimedechristian@yahoo.com \\ Other Authors Email: goodnewsonyeweaku@gmail.com,bionyananyo@yahoo.com
}

\begin{abstract}
This study was aimed at addressing the problematic taxonomy of the genus Cissus L. using three species namely; Cissus aralioides (Welw. ex Bak.) Planch, Cissus petiolata Hook.f and Cissus lageniflora Gilg and Brandt found in Obio/Akpor Local Government Area of Rivers State. The investigation was carried out using morphological, anatomical, epidermal and phytochemical lines of evidence. Macromorphology results showed that Cissus aralioides, Cissus lageniflora and Cissus petiolata matured leaf possess digitately compound leaf type, trifoliate compound leaf type and simple leaf type respectively. Micromorphological results showed that all studied species were hypostomatic with anomocytic stomata type present in the abaxial surface of all species. Epidermal cell shape of the adaxial and abaxial surface of all species were pentagonal and irregular to polygonal respectively. Transverse sections of the petiole of studied species shows an arranged and open vascular bundles in all species, variations where however seen in the number of vascular bundles. Methanolic extract of the three cissus species studied revealed the presence of secondary metabolites like; Phenols, Alkaloids, Aglycone Glycosides, Cardiac Glycosides, Steroidal Aglycone Glycosides in the stem and leaf of all species. The results obtained shows that all studied species show diverse characteristic differences but these differences are not adequate and convincing enough to separate them into different genera but it shows that that Cissus aralioides and Cissus lageniflora are more closely related than they are to Cissus petiolate. Moreover, more species and other lines of evidence should be used in future research. A dendogram to the relatedness of the species and a dichotomous bracketed key to their identification is provided.
\end{abstract}

DOI: https://dx.doi.org/10.4314/jasem.v24i1.20

Copyright: Copyright (C 2020 Onyeweaku et al. This is an open access article distributed under the Creative Commons Attribution License (CCL), which permits unrestricted use, distribution, and reproduction in any medium, provided the original work is properly cited.

Dates: Received: 30 November 2019; Revised: 20 December 2019; Accepted: 23 December 2019

Keywords: Cissus species, Taxonomy, dichotomous key, Dendogram,

The genus Cissus L. belongs to the Family Vitaceae (formerly Ampelidacae) and comprises of about 350 species distributed all over the world (Airy Shaw, 1985; Eggli, 2002). Cissus represents the largest of the 14 genera of Vitaceae (Lombardi, 2007; Wen, 2007; Wen et al., 2007). The genus has about 135 species in Africa, 85 species in Asia, 12 species in Australia and 65 species in the Neotropics (Wen, 2007). It is worthy of note that 49 of the 135 species that are present in Africa are found in West Africa with 23 and 15 of these in southern and northern Nigeria respectively, making a total of 38 species present in Nigeria (Hutchinson and Dalziel, 1954; Burkill, 2000). Vitaceae (grape family) sensu lato is of great economic importance, but there is little understanding of the relationships between and within the genera, the traditional classifications of grouping some Cissus species (e.g. Cissus artarctica Vent.) in a clade with Vitis species and placing Cissus species (e.g. Cissus quadrangularis L.) in a monophyletic clade have been countered by recent DNA based phylogenetic studies (Susan et al., 2007).
Members of the genus Cissus shows remarkable morphological diversity (Lombardi, 2007), and is generally characterized by well-developed thick and undivided floral disks, four merous flowers, one seeded fruits and seeds with a long and linear chalaza (Wen, 2007; Chen and Manchester, 2011). It is noteworthy that the members of the genus Cissus are climbing shrubs, small tress or herbs from a perennial root stock, with nodes or jointed stem, often with watery juices. It is noteworthy that phylogenic studies have also moved some other species to another genus, Cayratia (Bak.) Suess (Maurizio et al., 2007). Examples of these species are Cayratia debilis (Bak.)Suess. Basionynm: Cissus debilis (Bak.)Planch, Cayratia gracilis (Guil and Perr) Suess. Basionym: Cissus gracilis Guil and Perr, Cayratia ibuensis (Hook.f.) Suess. Basionym: Cissus ibuenis Hook.F. (Burkill, 2000). Therefore the objective of this paper is to present detailed characters of the studied species from four taxonomic line of evidence that will be analyzed with a dendogram to give the relatedness of the species. 


\section{MATERIALS AND METHODS}

Collection and identification of plant materials: Fresh and healthy plant samples of the genus Cissus L. were collected in separate bags from areas within the University of Port Harcourt Park, Choba Park all in the University of Port Harcourt Campus, Choba in ObioAkpor Local Government Area of Rivers State. Specimens were also collected from Wokem's estate in Choba community in Obio-Akpor Local Government Area of Rivers State. The plant specimens were identified at the herbarium of the Department of Plant Science and Biotechnology, University of Port Harcourt, Rivers State. Voucher specimens were deposited in the herbarium for reference and further studies.

Macromorphological Investigation: Examinations on the macromorphological characters of the Cissus species which are of taxonomic interest were performed in matured living plant samples. Both qualitative and quantitative vegetative features were studied. Quantitative features studied were made possible by the aid of meter-rule and measuring tape. Also photographs of relevant morphological features were taken. Plates 1a-1c gives a pictorial representation and view of the species.

Micromorphological Investigation: Foliar materials for epidermal studies were collected fresh from plants growing in the wild. The adaxial and abaxial epidermal surfaces were peeled with blades and in some cases, they were soaked in concentrated Nitric acid or Trioxonitrate (v) acid, rinsed in distilled water and then stained in $1 \%$ aqueous safranin solution and mounted in glycerin. Thereafter, the cover slips were placed over the peels and then sealed with nail varnish to prevent dehydration (Agbagwa and Okoli, 2007; Ekeke et al., 2019). The slides were observed using a microscope and pictures were taken with the use of a camera and the leaf epidermal characteristics were determined based on the methods of Metcalfe and Chalk (1979).

Anatomical Studies: Cut sections of petiole and young stems were fixed in FAA (Formaldehyde: Glacial Acetic Acid: Alcohol in the ratio of 1:1:18) for at least 48 hours according to Johasen (1940). Then removed and washed in distilled water after which the specimen was dehydrated in $30 \%, 50 \%, 70 \%$ and absolute ethanol series for 2 hours each. Thereafter, the specimens were placed in $3: 1,1: 1$, and $1: 3$ absolute ethanol: chloroform mixture, for 3 hours each. The specimen was rinsed in pure chloroform. The specimen once again was passed through the ethanol series for 2 hours each from $70 \%, 50 \%$ and then $30 \%$ ethanol. The specimen was then sectioned and stained with $1 \%$ aqueous safranin and counter stained with Alcian blue and then rinsed in water and finally mounted on the slide, glycerin was added and then covered with cover slip and sealed with nail polish. The slides were viewed using the microscope and pictures were taken with the aid of a camera.

Phytochemical Investigation: Preparation of solvent extract: Fresh plant parts (stem and leaves) were collected from their natural habitat in separate sterile polythene bags for each of the selected species. The plants were oven dried in the oven of the University of Port Harcourt herbarium for 6-8 days to reduce the moisture content in the samples. The dried samples were collected from the oven and crushed or grounded using the porcelain mortar. It is worthy of note that the stem and leaves of the plants were crushed separately. $10 \mathrm{mls}$ of methanol was then added to each of the samples for extraction. The extraction was done at room temperature.

Qualitative analysis of methanolic extract of samples: The following standard protocols as stated by Harborne (1973), Edeoga et al. (2005), Sofowora (2008), Nyananyo and Nyingifa (2011), Catherine and Banu (2015) and Rahman et al. (2017) were used for qualitative analysis of methanolic extract of samples for the presence of alkaloids, phenols, saponins, cardiac glycosides, aglycone glycosides, steroidal aglycone glycosides, tannins, terpenoids, steroids and flavonoids. Mayer's test for alkaloids, Keller-Kilian test for Cardiac glycosides, Salkowiski's test for Steroidal Aglycone glycosides, Liebermann's test for Aglycone glycosides, Follin-denis reagent test for tannin and paper chromatography etc.

Numerical Analysis: Taxonomic characters obtained from the morphological, phytochemical and anatomical investigations of (3) species of the Cissus genus were grouped by cluster analysis using the single linkage method based on similarity matrix of Euclidean distances of quantitative and qualitative characters. This statistical analysis was done using the Paleontological statistics (PAST) software.

\section{RESULTS AND DISCUSSIONS}

Macromorphological description: Important Macromorphological differences and similarities observed in the three Cissus species studied are summarized in table 1 . While the pictures of the studied species showing distinguishing features are presented in Plates 1a - 1c. Micromorphological Investigation: Abaxial and adaxial surface of the studied species are presented in plate $2 \mathrm{a}-2 \mathrm{f}$, while table 2 highlighted the important features in all species. Phytochemical Investigation: The preliminary 
phytochemical analysis of some of the tropical plants investigated in the study area were evaluated and results presented in table 2 .

Table 1: Summary of the important macro morphological attributes of the studied species

\begin{tabular}{llll}
\hline Characters & Cissus aralioides & Cissus lageniflora & Cissus petiolata \\
\hline Leaf type & Digitately compound & Trifoliate compound & Simple \\
Leaf arrangement & Opposite & Opposite & Opposite \\
Leaf shape & Oblong & Lanceolate & Sagitate \\
Leaf apex & Acuminate & Aristate & Aristate \\
Leaf base & Cuneate & Oblique & Cordate \\
Leaf margin & Lobed & Parted & Parted \\
Leaf venation & Pinnately veined & Pinnately veined & Pinnately veined \\
Abaxial leaf pigmentation & Absent & Present & Present \\
Glabrous or pubescent on leaf & Glabrous & Pubescent & Pubescent \\
Leaf length & $11.0-12.6 \mathrm{~cm}$ & $9.0-10.5 \mathrm{~cm}$ & $15.5-17.5 \mathrm{~cm}$ \\
Leaf width & $4.8-5.0 \mathrm{~cm}$ & $4.0-4.7 \mathrm{~cm}$ & $12.5-16.5 \mathrm{~cm}$ \\
Shape of stem & Cylindrincal & Circular & Circular \\
Stem pigmentation & Present & Present & Present \\
Stipule & Present & Absent & Present \\
Length of tendril & $23.0-25.0 \mathrm{~cm}$ & & $24.5-26-5 \mathrm{~cm}$ \\
Tendril Branching & Absent & Absent & Present \\
Length of petiole & $7.0-8.0 \mathrm{~cm}$ & $5.5-6.5 \mathrm{~cm}$ & $11.5-13.5 \mathrm{~cm}$ \\
Glabrous or pubescent on stem & Glabrous & Glabrous & Pubescent \\
\hline
\end{tabular}
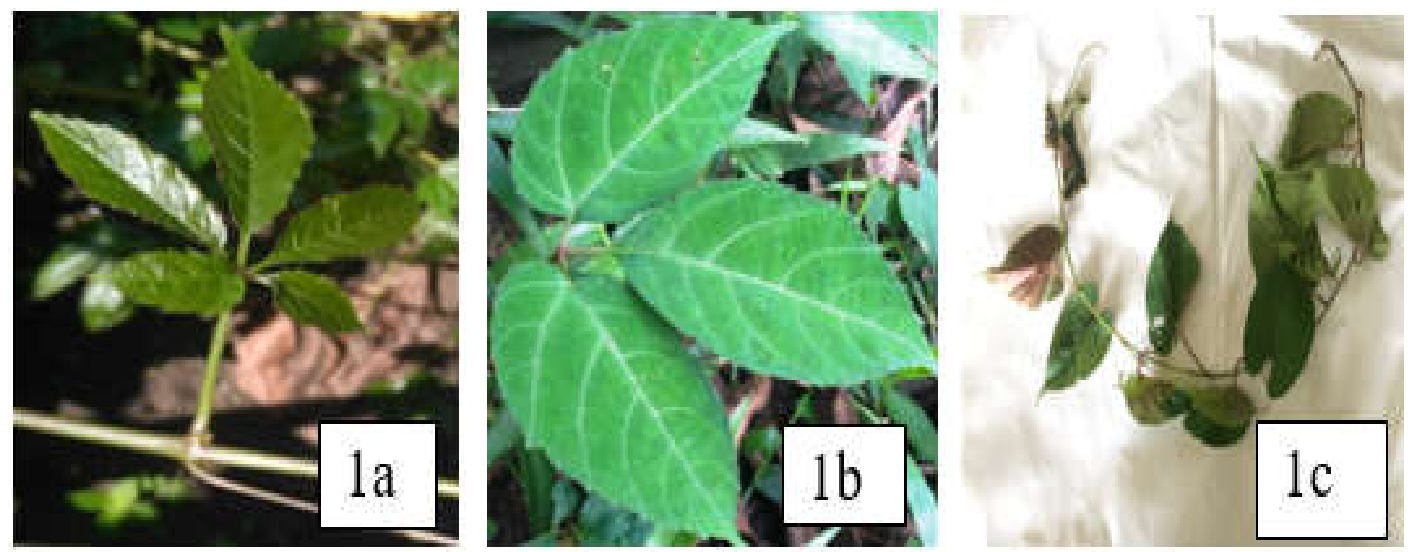

Plate 1a-1c: (1a) Cissus aralioides matured leaf showing digitately compound leaf type, oblong leaf shape, acuminate and cuneate leaf apex and base respectively (1b) Cissus lageniflora matured leaf showing Trifoliate compound leaf type, Lanceolate leaf shape, parted leaf margin with aristate and Oblique leaf apex and base respectively (1c) Cissus petiolata showing simple leaf type, Sagitate leaf shape, aristate and cordate leaf apex and base respectively with parted leaf margin.
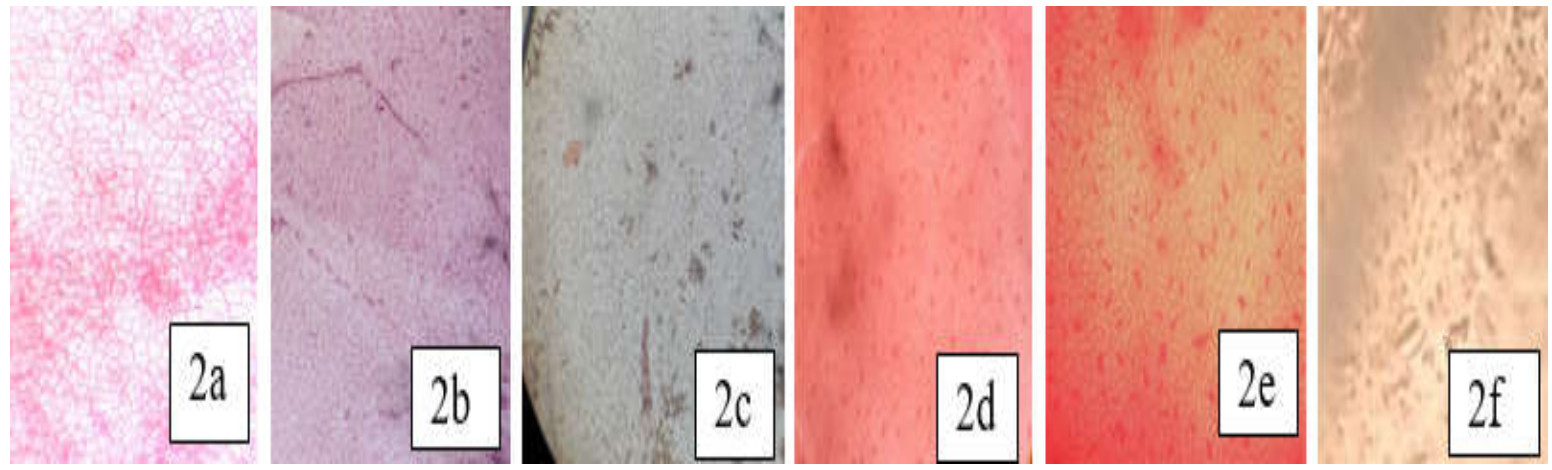

Plate: 2a-2f: All studied species were hypostomatic with anomocytic stomata type present in the abaxial surface of all species. Epidermal cell shape of the adaxial and abaxial surface of all species were pentagonal and irregular to polygonal respectively. Variations were however observed in the presence or absence of trichomes. (2a) Adaxial surface of Cissus aralioides (2b) Adaxial surface of Cissus lageniflora (2c) Adaxial surface of Cissus petiolate with arrow showing presence of trichomes. (2d) Abaxial surface of Cissus aralioides (2e) Abaxial surface of Cissus lageniflora (2f) Abaxial surface of Cissus petiolata showing trichomes. 
Anatomical studies (Petiole)
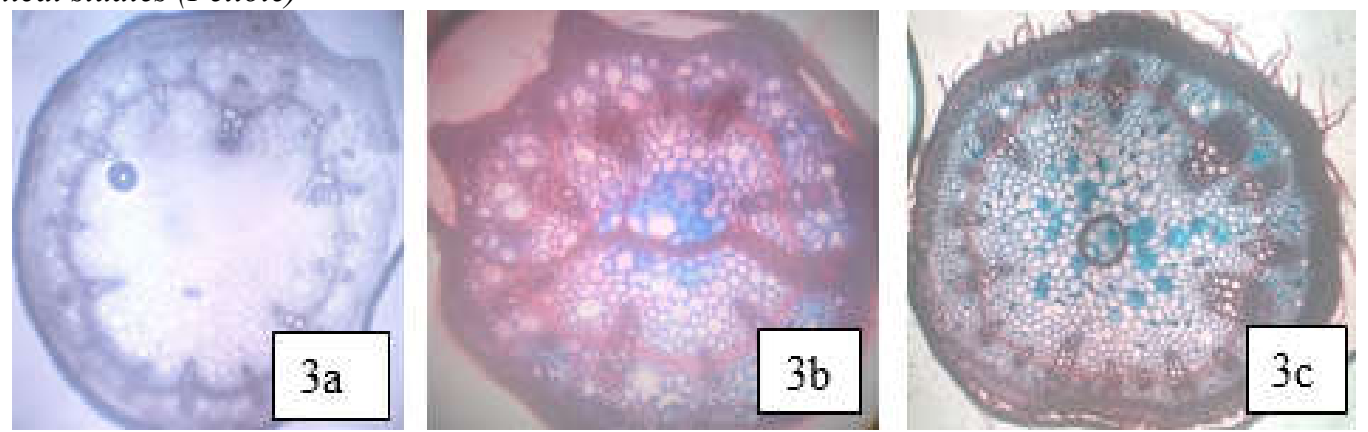

Plate 3a-3c: Transverse sections of the petiole of studied species shows an arranged and open vascular bundles in all species, variations where however seen in the number of vascular bundles as well as in the nature of the Intercellular spaces. (3a) Transverse section of the petiole of Cissus aralioides showing absence of schlerids, raphid bundles and trichomes. 17 vasclar bundles were observed (3b) Transverse section of the petiole of Cissus lageniflora showing 11 vascular bundles. Schlerids and raphid bundles were observed while trichomes were absent (3c) Transverse section of the petiole of Cissus petiolata showing 18 vascular bundles. Schlerids and raphid bundles were absents. With arrow showing the presence of trichomes.

\section{STEM}
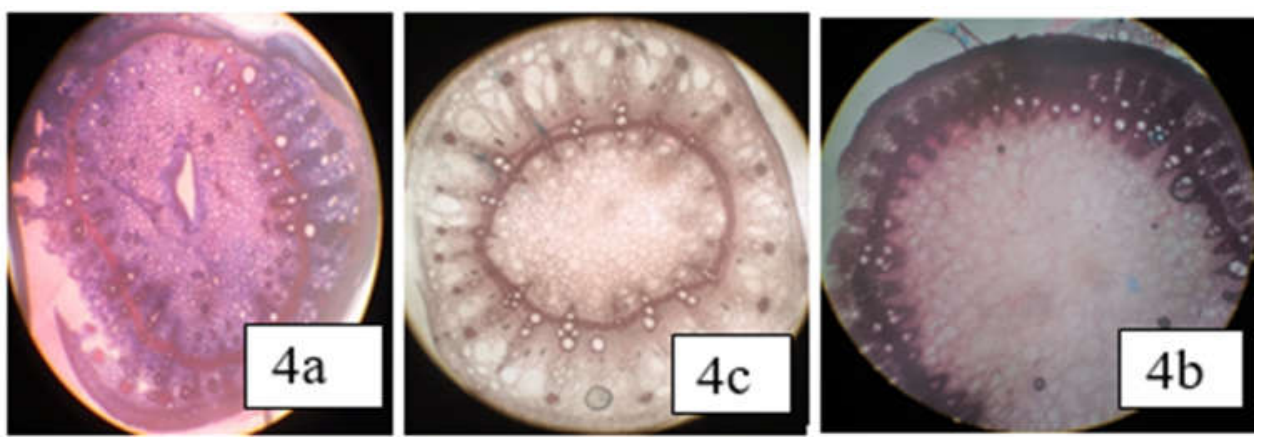

Plate 4a-4f: Transverse sections of the stem of studied species shows an arranged and open vascular bundles in all species, variations where however observed in the nature of the Intercellular spaces as well as in the presence or absence of trichomes (4a) TS of the stem of Cissus aralioides (4b) TS of the stem of Cissus lageniflora (4c) TS of the stem of Cissus petiolate with arrow showing trichomes.

Table 2: Preliminary phytochemical analysis of Cissus species studied.

\begin{tabular}{lllllll}
\hline Phytochemicals & \multicolumn{2}{l}{ Cissus aralioides } & \multicolumn{2}{c}{ Cissus lageniflora } & \multicolumn{2}{c}{ Cissus petiolata } \\
& Leaf & Stem & Leaf & Stem & Leaf & Stem \\
\hline Saponins & - & + & + & ++ & ++ & + \\
Tannins & ++ & - & - & - & +++ & - \\
Phenols & + & + & + & + & + & + \\
Terpenoids & + & ++ & ++ & + & ++ & ++ \\
Steroids & - & - & - & - & ++ & - \\
Alkaloids & ++ & + & ++ & ++ & ++ & ++ \\
Aglycone Glycosides & +++ & ++ & ++ & ++ & ++ & ++ \\
Cardiac Glycosides & ++ & +++ & ++ & ++ & ++ & +++ \\
Steroidal Aglycone & ++ & +++ & ++ & +++ & + & ++ \\
Glycosides & & & & & & \\
Apiginine & + & - & + & - & + & - \\
Kayaflavone & + & - & - & - & + & - \\
Tricin & + & - & + & - & + & - \\
Chrysoeriol & + & - & + & + & + & - \\
Luteolin & + & + & - & - & + & - \\
Gossypetin & - & + & - & - & - & - \\
Quercetin & - & + & - & - & - & - \\
Azelatin & - & - & - & + & - & - \\
Iso-vitexin & - & - & - & - & - & - \\
Kaempferol & - & - & - & - & - & + \\
Iso-orientin & - & - & - & - & - & + \\
Vitexin & - & - & - & + & - & - \\
Orientin & - & + & - & - & - & - \\
\hline
\end{tabular}

+++ : highly present, ++: moderately present, + : Low, $-:$ absent 


\section{Numerical taxonomy}

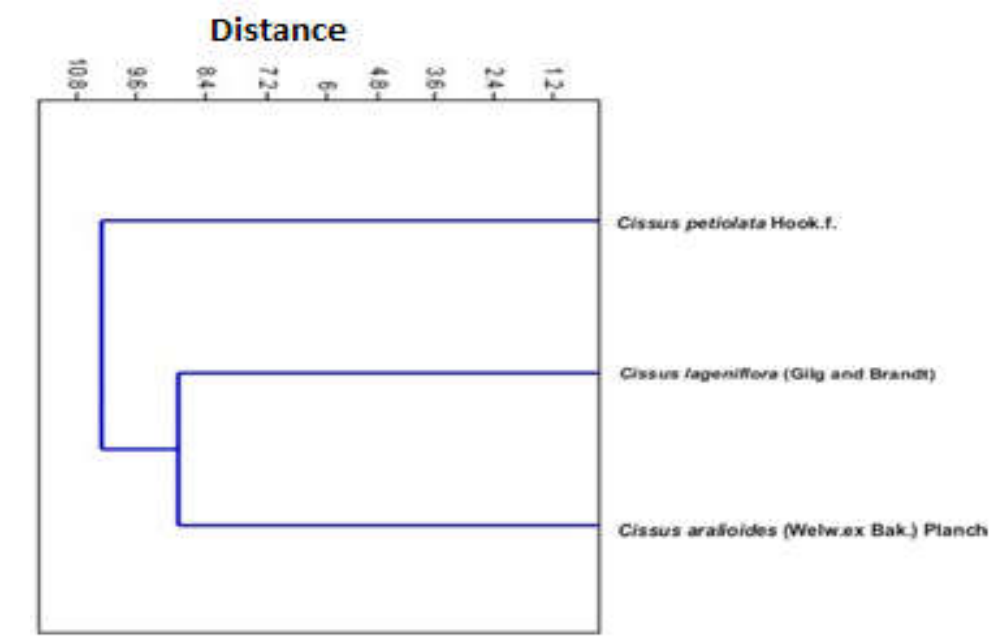

Fig 2: Dendogram of the three Cissus species studied produced by cluster analysis using Past

Dichotomous bracketed key for identification of the species:

1. Leaf pubescent, apices aristate, margin parted, trifoliate and simple leaf type present, stem circular, the flavonoid; vitexin present, gossypetin, quercetin, luteolin and orientin absent in stem and saponin present in the leaf......2

1'.Leaf glabrous, apex acuminate, margin lobed, stem cylindrical, digitately compound, flavonoid; vitexin absent, gossypetin, quercetin, luteolin, orientin, present in stem, saponin absent in leaf ........issus aralioides.

2.Trichomes present on stem, petiole and the abaxial and adaxial surfaces of the leaf epidermis, simple leaf present, stem pubescent, stipule present, leaf base cordate, shape sagitate, the flavonoids; kaempferol and iso-vitexin present in stem, luteolin and kayaflavone present in the leaf,chrysoeriol absent in stem and leaf....... Cissus petiolata.

2'. Trichomes absent on stem, petiole, and abaxial and adaxial surfaces of the leaf epidermis, trifoliate compound leaf present, stem glabrous, stipule absent, leaf base oblique, shape lanceolate, the flavonoids; kaempferol and iso-vitexin absent in the stem, luteolin and kayaflavone absent in leaf, chrysoeriol is present in stem and leaf.......Cissus lageniflora.

Results obtained from the morphological study of the three Cissus species were in conformity with the report of Hutchinson and Dalziel (1954) and Burkill, (1985). Cissus aralioides and Cissus lageniflora show robust morphological similarity with regards to their stem pigmentation, phyllotaxy and leaf type. Although a good number of differences occur among them and these differences are presented in Table 1 and Plate 2a- 2c above. Cissus petiolata nonetheless expresses quite a different form of morphological existence when compared to Cissus aralioides and Cissus lageniflora.

Methanolic extract of the three cissus species studied revealed the presence of secondary metabolites like; Phenols, Alkaloids, Aglycone Glycosides, Cardiac Glycosides, Steroidal Aglycone Glycosides in the stem and leaf of all species. For Cissus aralioides, the compounds tannins and saponins were found in traces and this is in conformity with the study of Omotayo and Borokini (2010) and Nwogueze et al. (2018). For Cissus lageniflora It is worthy of note that the secondary metabolites steroids and tannins were absent while terpenoids were found in traces. While the compounds steroids and phenols were found in traces for Methanolic leaf and stem extract of Cissus petiolata.

The leaf epidermal studies of the species showed slight variations among the three species as shown in plates $2 \mathrm{a}-2 \mathrm{f}$. The presence of trichomes (plate $2 \mathrm{c}$ ) is a unique character to delineate Cissus petiolate. It is noteworthy that the species were hypostomatic with anomocytic stomata type found in all, also, the shape of the epidermal cells in both adaxial and abaxial surface were similar.

The anatomical study shows little variation among studied species. For the petiole and stem anatomy of the species, a number of similarities were noticed and some of these are that the vascular bundles are arranged and open as well as the presence of interfasicular cambium ring which indicates that the species undergo secondary growth. The epidermal circumference of the petiole of Cissus aralioides (plate $3 \mathrm{a}$ ) and Cissus lageniflora (plate 3b) was angular with 
protuberance but was observed to be round without protuberance in Cissus petiolata (plate 3c).

The dendogram produces two groups at point 9.6 along the distance. The first group is made up of Cissus aralioides and Cissus lageniflora showing that they are more closely related while the second group consists of only Cissus petiolata.

Conclusion: The three Cissus species in this research work (Cissus aralioides, Cissus lageniflora and Cissus petiolata) although showed some characteristic differences but these differences are not enough to separate them into different genera. It is worthy of note that based on the dendogram constructed using characters from macromorphology, micromorphology, anatomy and phytochemistry Cissus aralioides and Cissus lageniflora are more closely related than they are to Cissus petiolate. However, further research should be carried out with other lines of evidence with a larger number of species that are members of the genus Cissus L. and as well some members of the genus Cyphostemma and Cayratia

\section{REFERENCES}

Agbagwa, IO; Okoli, BE (2007). Fruit epidermal features in the systematics of Abrus adanson (Papilionaceae) in parts of Tropical West Africa. J. Econ. Taxon. Bot., 31: 845-857

Airy Shaw, HK (1985). A dictionary of the flowering plants and ferns. Cambridge University Press, London. 1245 pp

Burkill, HM (2000). The useful plants of West Tropical Africa. Royal Botanic Gardens, Kew, London. 873 pp.

Catherine, L; Banu, SK (2015). General techniques involved in phytochemical analysis. Int. J. Adv. Res. Chem. Sci., 2(4):25-32

Chen, I; Manchester, SR (2011). Seed morphology of Vitaceae. Int. J. Plant Sci., 172:1-35

Edeoga, HO; Okwu, DE; Mbaebi, BO (2005). Phytochemical constituents of some Nigerian medicinal plants. Afr. J. Biotechnol., 4(7): $685-$ 688

Eggli, UR (2002). Illustrated Handbook of succulent plants: Dicotyledons. Springler, Germany. 323 pp

Ekeke, C; Elechi, A; Okoli, BE (2019).Karyological and anatomical studies on Syngonium podophyllum Schott (Araceae). Ife J. Sci., 21(1):001-009

Harbone, JB (1973). Phytochemical methods: A Guide to modern techniques of plant analysis. Chapman and Hall limited. London. 270 pp

Hutchinson, J; Dalziel, JM (1954). Flora of West Tropical Africa.Volume 1, second edition. Crown Agents for Oversea Governments and Administrations. London. 828 pp

Lombardi, JA (2007). Systematics of Vitaceae in South America. Can. J. Bot., 85:712-721

Lu, L; Wang, W; Chen, Z; Wen, J (2013). Phylogeny of the non-monophyletic Cayratia Juss. (Vitaceae) and implications for character evolution and biogeography. Mol. Phylogenet. Evol., 68:502-515

Maurizio, R; Darren, MC; Betsy, RJ; Carolyn, P (2007). An updated estimate of intergeneric phylogenetic relationships in the Australian Vitaceae. Can. J. Bot., 85(8):722-730

Metcalfe, CR; Chalk, L (1979).Anatomy of dicotyledons. The Clarendon Press, Oxford, London. $691 \mathrm{pp}$.

Nwogueze, B.C., Anachuna, K.K., Eke, C.N. and Ufearo, C.S. (2018). Toxic studies and phytochemical screening of aqueous extract of Cissus aralioides plant. J. Adv. Med. Pharmaceut. Sci., 17(1): 1-7

Nyananyo, BL; Nyingifa, AL (2011).Phytochemical investigation on the seed of Sphenostylis stenocarpa (Hochst. ex A.Rich.) Harms. Fabaceae. J. Appl. Sci. Environ. Manag., $15(3): 419-423$

Omotayo, FO; Borokini, IF (2010).Comparative phytochemical and ethno medicinal survey of selected plants in Nigeria. Sci. Res. Essays., 7(9):989-999

Rahman, G; Syned, UJ; Syned, F; Samiullah, S; Nusrat, J (2017). Preliminary phytochemical screening, quantitative analysis of alkaloids and antioxidant activity of crude plant extracts from Ephedra intermadia indigenous to Balochistan. Sci. World J., 2017:1-7

Soejima, A; Wen, J (2016). Phylogenetic analysis of the grape family (Vitaceae) based on the three chloroplast markers. Am. J. Bot., 93(2): 278-287 
Sofowora, A (2008). Medicinal plants and traditional medicine in Africa. Spectrum books limited, Ibadan, Nigeria. 202 pp

Susan, AT; Usher, P; Jean, MG (2007). Morphological and anatomical development in the Vitaceae and comparative ontogeny and phylogenetics implications of Cissus quadrangularis L. Can. J. Bot., 85(9):860-872.
Wen, J (2007). Vitaceae, The Families and genera of vascular plants. Springer-Verlag-Berlin, Germany.478 pp.

Wen, J; Nie, ZL; Soejima, A; Meng, Y (2007). Phylogeny of Vitaceae based on the nuclear GAI1 gene sequences. Can. J. Bot., 85:731-745. 